\title{
PENINGKATAN AKTIVITAS BELAJAR SISWA MELALUI METODE PICTURE AND PICTURE
}

\author{
Daswati \\ Sekolah Menengah Pertama Negeri (SMPN) 2 Pariangan Tanah Datar \\ dasswatidra@gmail.com
}

\begin{abstract}
Based on the experience and observation of the author about the condition in SMP Negeri 2 Pariangan class VII 1 in the school year 2016 - 2017, students seemed less involved in the learning process. This was because the method of learning used by teachers that have not varied so as not interesting for students. This study aimed to determine whether the use of picture and picture method could improve student learning activities in class VII.1 SMPN 2 Pariangan Tanah Datar. This research was conducted through Classroom Action Research which was conducted in 2 cycles. The results of this study indicated that the use of Picture and Picture method was able to improve student learning activities. This could be seen from the average of student activity reaching $84 \%$ in learning which previously only at $52 \%$.
\end{abstract}

Keywords: Learning activity, Picture and Picture method, civic education.

Submitted: September 6, 2020

Reviewed: October 14, 2020

Published: November 7, 2020

How to Cite: Daswati. 2020. Peningkatan Hasil Belajar Siswa melalui Metode Picture and Picture di Kelas VII 1 SMPN 2 Pariangan. Vol 4 (2): pp. 197-210. DOI: https://doi.org/10.24036/jess.v4i2

\section{Pendahuluan}

Dalam Undang-undang Republik Indonesia nomor 20 tahun 2003 Tentang Sistem Pendidikan Nasional Bab III pasal 3 dinyatakan bahwa Pendidikan Nasional berfungsi mengembangkan kemampuan dan membentuk watak serta peradaban bangsa yang bermartabat dalam rangka mencerdaskan kehidupan bangsa. Selanjutnya dijelaskan pula bahwa pendidikan nasional bertujuan untuk berkembangnya potensi peserta didik menjadi manusia yang bertaqwa kepada Tuhan Yang Maha Esa, berakhlak mulia, sehat, berilmu, kreatif, mandiri, dan menjadi warga negara yang demokratis serta bertanggung jawab. Tujuan pendidikan nasional ini secara tidak langsung juga menjadi tujuan pendidikan kewarganegaraan.

Namun dalam kenyataannya, dalam proses pembelajaran Pendidikan Kewarganegaraan di SMP Negeri 2 Pariangan Kabupaten Tanah Datar kelas VII 1, guru masih sering menerangkan pelajaran dengan metode pembelajaran konvensional, terutama metode ceramah dan siswa mendengarkan kemudian mencatat pelajaran yang diberikan. Media yang digunakan tidak memadai dan kegiatan belajar menjadi tidak menarik. Sebagian besar siswa sangat jarang, bahkan 
tidak terlibat dalam hal mengajukan pertanyaan atau mengutarakan pendapat, walaupun guru sudah berulang kali meminta siswa untuk bertanya.

Selain itu, kalau ada hal-hal yang kurang jelas dan yang belum dimengerti siswa terkesan takut dan malu untuk bertanya. Sebaliknya, ketika guru bertanya, tidak ada satupun siswa yang mau menjawab pertanyaan. Banyak siswa yang tidak memperhatikan penjelasan guru dan pada kenyataannya banyak siswa terlihat malas, tidak percaya diri mengerjakan soal-soal latihan, dan kurangnya aktivitas pembelajaran. Dalam proses pembelajaran siswa sudah terbiasa mendengarkan informasi yang diberikan oleh guru. Sangat jarang, bahkan tidak ada siswa yang bertanya dalam proses pembelajaran, dalam arti siswa tidak aktif dalam proses pembelajaran. Untuk itu perlu metode pembelajaran yang tepat dan sesuai akan sangat membantu tercapainya tujuan pembelajaran. Penggunaan metode pengajaran yang kurang menarik dapat menimbulkan suatu masalah, yaitu rendahnya motivasi belajar siswa (Fauzi, R., Dwiastuti, S. 2011)

Kondisi di atas memperlihatkan bahwa siswa kurang terlibat dalam proses pembelajaran, seperti bertanya, mengemukakan pendapat, mengerjakan tugas, dan memperhatikan penjelasan guru. Hal ini juga megindikasikan bahwa aktivitas siswa rendah. Jika kondisi ini dibiarkan terus-menerus, maka aktivitas peserta didik pada mata pelajaran Pendidikan Kewarganegaraan tidak akan meningkat. Dengan demikian permasalahan tersebut harus segera diatasi. Solusi pemecahan masalah adalah memilih model pembelajaran Picture and Picture dalam penelitian tindakan kelas, karena model pembelajaran ini sudah pernah diterapkan oleh pihak lain dan mencapai keberhasilan yang memuaskan (Passalowongi 2020)

Model Picture and picture merupakan model pembelajaran dengan memanfaatkan media gambar. Melalui Picture and picture diharapkan aktivitas belajar siswa akan lebih baik. Pemahaman siswa diharapkan lebih baik sehinga prestasi belajar siswa meningkat (Meiyanto and Suwarsih 2018).

Diperlukan suatu pembelajaran yang memiliki ciri khas pembelajaran yang menarik, inovatif, kreatif, dan aktif. Oleh karena itu, diperlukan perencanaan mengenai pemilihan metode pembelajaran yang sesuai untuk diterapkan dalam pembelajaran. Salah satu metode pembelajaran yang memiliki ciri menyenangkan, inovatif, kreatif, dan aktif yaitu metode picture and picture (Sudarsana, Adnyani, and Suartini 2018). Hamdani (dalam Dewi, 2013) menyatakan bahwa picture and picture merupakan suatu metode belajar menggunakan gambar yang dipasangkan atau diurutkan menjadi urutan logis. Picture and picture ini berbeda dengan media gambar dimana picture and picture berupa gambar yang belum disusun secara berurutan dan yang menggunakannya adalah siswa, sedangkan media gambar berupa gambar utuh yang digunakan oleh guru dalam proses pembelajaran (Natalina, Yusuf, and Rahmayani 2012).

Berdasarkan permasalahaan di atas, pada penelitian ini penulis sebagai guru Pendidikan Kewarganegaraan merasa perlu untuk menerapkan suatu strategi pembelajaran yang dapat meningkatkan aktivitas peserta didik. Strategi yang digunakan adalah dengan cara melaksanakan proses kegiatan belajar melalui penggunaan metode pembelajaran Picture and Picture. Untuk itu penulis mengangkat judul tentang "Peningkatan Aktivitas Belajar Siswa melalui Metode Picture and Picture di kelas VII 1 SMP Negeri 2 Pariangan". 
Berdasarkan analisis latar belakang dan identifikasi permasalahan di atas maka masalah yang akan diteliti dalam penelitian ini dirumuskan sebagai berikut: "Apakah aktivitas belajar siswa dapat ditingkatkan melalui metode Picture and Picture dalam mata pelajaran pendidikan Kewarganegaraaan di kelas VII 1 SMP Negeri 2 Pariangan, Kabupaten Tanah Datar?". Penelitian ini bertujuan untuk mendeskripsikan penggunaan metode Picture and Picture dalam rangka peningkatan aktivitas belajar siswa dalam pembelajaran Pendidikan Kewarganegaraan di kelas VII 1 SMP Negeri 2 Pariangan Kabupaten Tanah Datar

\section{Tinjauan Kepustakaan}

\section{Aktivitas Belajar}

Aktivitas merupakan hal penting dalam pembelajaran sebab belajar pada prinsipnya merupakan perubahan tingkah laku. Menurut Sardiman (2007) "tidak ada belajar kalau tidak ada aktivitas". Untuk mengelompokkan aktivitas yang sedang berlangsung Sardiman (2007) membedakan aktivitas tersebut menjadi beberapa bagian yaitu: 1) Visual activities; 2) Oral activities; 3) Listening activities; 4) Writing activities; 5) Drawing activities; 6) Motor activities; 7) Menthal activities; dan 8) Emotional activities.

Selanjutnya, belajar adalah suatu proses perubahan tingkah laku atau pribadi seseorang berdasarkan praktek dan pengalaman tertentu. Menurut Slameto (2015) untuk memperoleh suatu perubahan tingkah laku yang baru secara keseluruhan, sebagai hasil pengalamannya sendiri dalam interaksi dengan lingkungannya. Sementara Hamalik (2008) pelajaran mengandung arti setiap kegiatan yang dilakukan untuk membantu seseorang dalam mempelajari suatu kemampuan atau nilai yang baru. Jadi peran guru dalam pembelajaran untuk membantu siswa dalam proses belajar, guru harus dapat mengusahakan suasana pembelajaran yang dapat menjadikan siswa aktif.

Disamping itu Sagala (2003) mengemukakan pula bahwa pembelajaran mempunyai dua karakteristik yaitu :

1. Dalam pembelajaran terdapat kegiatan melibatkan proses mental secara maksimal, bukan hanya menuntut siswa sekedar mendengar, mencatat, tetapi menghendaki aktivitas siswa dalam proses berfikir.

2. Dalam pembelajaran terdapat kegiatan membangun suasana dialogis dan proses tanya jawab terus menerus untuk memperbaiki dan meningkatkan kemampuan berfikir siswa yang pada gilirannya kemampuan berfikir itu dapat membantu siswa untuk memperoleh pengalaman yang mereka konstruksi sendiri.

\section{Metode Picture and Picture dalam Proses Pembelajaran}

Picture and Picture merupakan teknik pembelajaran yang menggunaka media gambar yang dapat menarik perhatian siswa, serta dapat membangun motivasi siswa dalam belajar (Mustikasari, Maddatauang, and Maru 2017). Menurut Suprijono (2011) metode picture and picture adalah metode pembelajaran yang menggunakan gambar dipasangkan atau diurutkan menjadi urutan logis. Dalam hal ini guru menyampaikan kompetensi yang ingin dicapai, menyampaikan materi 
pembelajaran sebagai pengantar. Sementara menurut Istarani (2014) metode picture and picture adalah metode pembelajaran dengan menggunakan gambar. Dalam operasionalnya gambar-gambar dipasangkan satu sama lain atau bisa jadi diurutkan menjadi urutan yang logis. Sedangkan menurut Hamdani (2011) metode picture and picture adalah metode belajar yang mengutamakan gambar dipasangkan atau diurutkan menjadi urutan logis. Pembelajaran ini memiliki ciri aktif, inovatif, kreatif dan menyenangkan (Nabilah and Gofur 2020).

Dari uraian beberapa pendapat di atas dapat disimpulkan bahwa metode picture and picture adalah metode yang menggunakan gambar dipasang atau diurutkan menjadi urutan yang logis melalui kartu. Di sekolah yang sudah menggunakaqn ICT dapat pula menggunakan slide power point atau software yang lainnya. Banyak metode pembelajaran yang dapat dipilih guru dalam melaksanakan pembelajaran, salah satunya ialah metode pembelajaran Picture and Picture. Dalam metode ini, penggunaan media gambar menjadi faktor utama selama pembelajaran yang nantinya gambar-gambar tersebut dipasangkan atau diurutkan secara logis dan sistematis (Ahmadi dalam Rakasiwi et al., 2019)

Adapun langkah-langkah metode picture and picture menurut Istarani (2014) adalah sebagai berikut :

1. Guru menyampaikan tujuan pembelajaran atau kompetensi yang ingin dicapai. Pada langkah ini guru diharapkan untuk menyampaikan apakah yang menjadi kompetensi dasar mata pelajaran yang bersangkutan. Dengan demikian maka siswa akan mengukur sampai sejauh mana harus dikuasainya.

2. Memberikan materi pengantar sebelum kegiatan. Penyajian materi sebagai pengantar sangat penting bagi siswa. Guru perlu memberikan momentum permulaan pembelajaran. Kesuksesan dalam proses pembelajaran dapat dimulai dari siswa. Karena guru dapat memberikan motivasi yang menarik perhatian siswa yang selama ini belum siap mengikuti pembelajaran.

3. Guru menyediakan gambar-gambar yang akan digunakan (sesuai dengan materi). Dalam proses pembelajaran materi, guru ikut terlibat aktif dalam proses pembelajaran dengan mengamati setiap gambar yang ditujukan oleh guru atau temannya. Dengan picture and picture kita akan menghemat energi kita dan siswa akan lebih mudah memahami materi yang diajarkan.

4. Guru menunjuk siswa secara bergilir untuk mengurutkan atau memasang gambar-gambar lain. Pada langkah ini guru dapat memberikan motivasi dan inovasi, karena penunjukan secara langsung kadang kurang efektif dan siswa merasa terhukum.

5. Guru memberikan pertanyaan mengenai alasan siswa dalam menentukan urutan gambar. Setelah itu ajaklah siswa menemukan jalan cerita atau tuntutan KD.

6. Dari alasan tersebut guru dan siswa mempresentasikan hasil diskusi mengenai materi dan konsep materi yang sesuai dengan kompetensi yang ingin dicapai. Dalam proses diskusi dan pembacaan gambar ini guru harus memberikan penekanan-penekanan pada hal ini dicapai untuk meminta siswa mengulangi, 
menuliskan atau bentuk lain dengan tujuan siswa mengetahui bahwa hal tersebut penting dalam pencapaian KD dan indikator yang telah ditetapkan.

7. Guru dan siswa bersama-sama menyampaikan kesimpulan. Di akhir pembelajaran guru bersama siswa mengambil kesimpulan sebagai penguatan materi pembelajaran.

Sejalan dengan pendapat Istarani, Hamid (2012) mengemukakan bahwa langkah-langkah metode picture and picture adalah sebagai berikut:

1. Menyampaikan kopentensi yang ingin dicapai;

2. Guru menyajikan materi sebagai pengantar;

3. Guru menunjukkan atau memperlihatkan gambar-gambar kegiatan berkaitan dengan materi;

4. Guru menunjuk atau memanggil siswa secara bergantian untuk memasang atau mengurutkan gambar-gambar menjadi urutan logis;

5. Guru menanyakan alasan atau dasar pemikiran dari urutan gambar tersebut;

6. Dari alasan atau gambar tersebut guru menanamkam konsep atau materi sesuai dengan kompetensi yang ingin dicapai;

7. Guru memberi kesimpulan rangkuman dari materi yang dibahas.

Dalam penelitian ini peneliti menggunakan langkah-langkah metode picture and picture menurut Istarani.

\section{Kelebihan dan Kelemahan Metode Picture and Picture}

Menurut Istarani (2014) kelebihan metode picture and picture adalah sebagai berikut:

1. Materi yang akan diajarkan lebih terarah karena pada awal pembelajaran guru menjelaskan kompetensi yang harus dicapai dan materi secara singkat terlebih dahulu.

2. Siswa lebih cepat menangkap materi ajar karena guru menunjuk gambargambar melalui yang dipelajari.

3. Dapat meningkatkan daya nalar atau daya pikir siswa karena siswa disuruh untuk menganalisa gambar yang ada.

4. Dapat meningkatkan tanggung jawab siswa, sebab guru menanyakan alasan siswa mengurutkan gambar

5. Pembelajaran lebih berkesan, sebab siswa dapat mengamati lansung gambar yang telah dipersiapkan oleh guru.

Sedangkan menurut Hamdani (2011) kelebihan metode picture and picture adalah sebagai berikut:

1. Guru lebih mengetahui kemampuan masing-masing siswa.

2. Melatih berfikir strategis atau sistematis.

3. Membatu siswa belajar berfikir berdasarkan sudut pandang suatu objek balasan dengan memberikan kebebasan siswa dalam praktek berfikir.

4. Mengembangkan motivasi untuk belajar yang lebih baik.

5. Siswa dilibatkan dalam perencanaan dan pengelolaan kelas. 
Selain mempunyai kelebihan, metode picture and picture juga mempunyai beberapa kelemahan. Menurut Istarani (2014) kelemahan metode picture and picture adalah sebagai berikut:

1. Sulit menemukan gambar-gambar yang bagus dan berkualitas serta sesuai dengan materi pembelajaran.

2. Sulit menemukan gambar-gambar yang sesuai dengan latar belakang nalar atau kompetensi yang dimiliki siswa.

3. Baik guru ataupun siswa kurang biasa dalam menggunakan gambar sebagai bahasan utama dalam membahas suatu materi pelajaran.

4. Tidak tersedianya dana khusus untuk menemukan atau mengadakan gambargambar yang diinginkan.

Sedangkan Hamdani (2011) berpendapat bahwa kelemahan metode picture and picture adalah sebagai berikut :

1. Memakan banyak waktu.

2. Banyak siswa yang pasif.

3. Guru khawatir bahwa akan terjadi kekacaun di kelas.

4. Banyak siswa tidak senang apabila disuruh bekerjasama dengan yang lain.

\section{Metode Penelitian}

Penelitian ini menggunakan penelitian tindakan kelas (classroom action research) yaitu studi yang sistematis dilakukan pelaku pendidikan dalam upaya meningkatkan suatu pembelajaran melalui tindakan yang terencana dan dampak dari tindakan yang telah dilakukan. Dalam penelitian ini, peneliti terlibat langsung dalam proses penelitian. Peneliti bertindak sebagai perancang, pelaksana, pengumpul data, penganalisa data dan pelapor penelitian dan bekerja sama dengan teman sejawat sebagai observer. Penelitian dilakukan di SMP Negeri 2 Pariangan yang berlokasi di Nagari Pariangan, Kecamatan Pariangan, Kabupaten Tanah Datar, yang berjarak lebih kurang 10 kilometer dari kota Batusangkar. Sekolah ini terdiri dari dari 6 kelas yang terdiri dari 2 kelas VII, 2 kelas VIII, dan 2 kelas IX dengan jumlah siswa 158 orang dengan 20 tenaga pengajar.

Analisis data penelitian tentang aktivitas siswa pada setiap pertemuan penelitian ini diinterpretasikan dalam bentuk persentase. Kegiatan penelitian dilakukan pada semester pertama dimulai pada bulan Agustus-Oktober tahun pelajaran 2016-2017, direncanakan 2 siklus dan selesai apabila target yang ditetapkan telah tercapai. Di akhir siklus diselenggarakan ulangan untuk memperoleh gambaran hasil tiap siklusnya.

\section{Hasil dan Pembahasan}

Pada bagian ini akan dipaparkan hasil penelitian dan pembahasan meningkatkan aktivitas siswa dengan metode picture and picture sesuai dengan langkah-langkah penelitian yang sudah dilakukan. Penggunaan gambar dalam pembelajaran materi memudahkan siswa memahami materi karena materi yang dianggap abstrak disajikan dalam bentuk dua dimensi (Riyono and Retnoningsih 2015). Penelitian ini dilaksanakan dalam dua siklus, setiap siklus terdiri dari dua kali pertemuan. 


\section{Siklus 1}

Sebelum melaksanakan pembelajaran di dalam kelas yang dijadikan fokus penelitian, peneliti menyusun RPP (Rencana Pelaksanaan Pembelajaran) dengan SK 1: Menunjukkan sikap positif terhadap norma-norma yang berlaku dalam kehidupan bermasyarakat, berbangsa dan bernegara. KD 1.1: Mendeskripsikan hakekat norma-norma, kebiasan, adat istiadat, peraturan yang berlaku dalam masyarakat, dengan menggunakan metode picture and picture dan menyiapkan materi dalam bentuk power point untuk klasifikasi pertemuan. Guru-guru menyiapkan lembaran observasi untuk melihat aktivitas siswa dan kegiatan guru dalam menggunakn metode picture and picture. Guru juga menyusun gambargambar secara tepat sesuai dengan materi yang akan dibahas.

Siklus 1 dilaksanakan dua kali pertemuan tanggal 5 September dan 19 September 2016.

\section{Pertemuan 1}

Pada pertemuan 1 siklus satu ini peneliti mulai melaksanakan metode picture and picture dalam pembelajaran. Proses pembelajaran dilaksanakan melalui tiga tahap: kegiatan awal, kegiatan inti, dan kegiatan penutup. Sesuai dengan tujuan penelitian yaitu menjelaskan aktivitas siswa melalui metode picture and picture maka pemantauan dilakukan melalui lembaran pengamatan terhadap aktivitas siswa.

Setelah melalui beberapa perencanaan penulis mulai melaksanakan metode picture and picture. Penulis mulai menampilkan gambar-gambar. Pada awalnya siswa agak sedikit gugup karena disuruh memperhatikan gambar dengan menjelaskan gambar yang dicermatinya sehingga aktivitas siswa agak terganggu. Observer terus mencatat dalam lembaran observasi setiap aktivitas siswa dan guru.

Berikut akan dipetakan grafik aktivitas siswa dan kegiatan guru dalam siklus 1 pertemuan 1 .

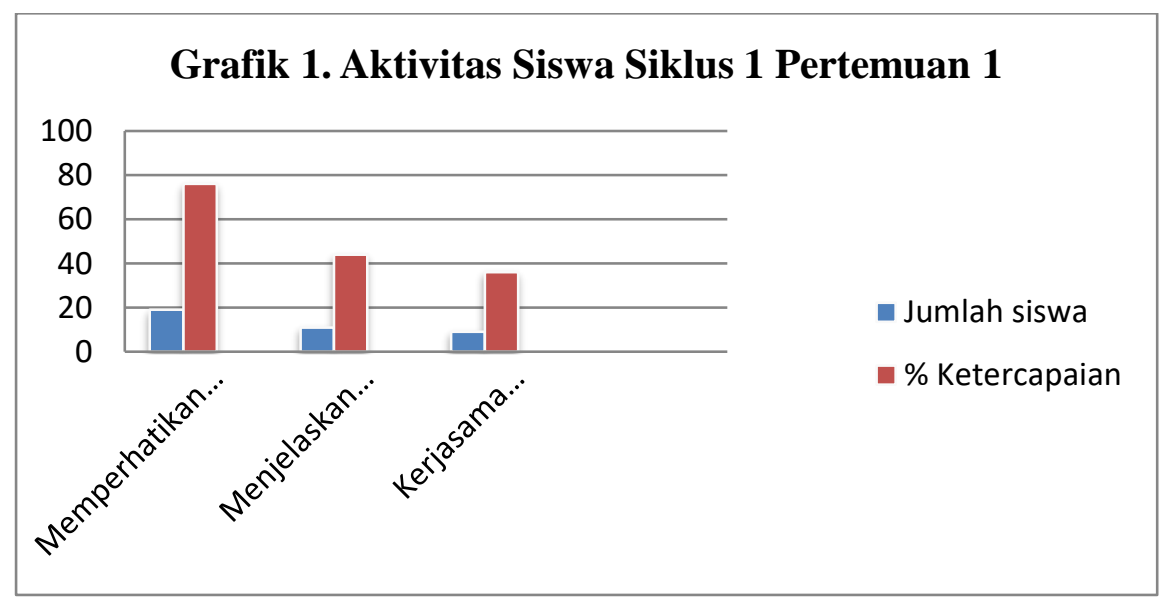

Proses pembelajaran yang berlangsung pada pertemuan 1 siklus 1 dapat berjalan sesusai dengan yang direncanakan. Namun dalam pelaksanaan masih banyak terdapat hal-hal yang harus mendapat perhatian serta diperbaiki oleh guru 
maupun siswa. Pada tahap ini siswa kelihatan kurang membaca dan belum memahami materi yang sesuai dengan gambar, sehingga siswa ragu untuk menjelaskan gambar serta mengkaitkannya dengan materi pembelajaran yaitu norma-norma dalam kehidupan bermasyarakat

Dalam pertemuan 1 siklus 1 ini hanya beberapa orang siswa yang kelihatan aktivitasnya, sementara siswa yang lain masih kurang.

\section{Pertemuan 2}

Berdasarkan refleksi pada pertemuan 1, maka disusunlah rencana pada pertemuan 2 agar terjadi perbaikan dalam proses pembelajaran. Rencana tindakan yang dilakukan pada pertemuan 2 adalah sebagi berikut:

1. Menugaskan siswa mempelajari materi pelajaran dengan sungguh-sungguh sebelum proses pembelajaran.

2. Mengupayakan siswa lebih aktif dalam memperhatikan, menjelaskan serta bekerjasama dalam menjelaskan gambar-gambar yang dilihatnya.

3. Menyusun Rencana Pelaksanaan Pembelajaran sesuai dengan langkah-langkah metode Picture and picture.

4. Menyiapkan lembaran observasi aktivitas siswa dan guru dalam pembelajaran. Memperhatikan serta memotivasi siswa yang kurang aktivitasnya

Pada pertemuan 2 siklus 1 ini tahap pertama yang dilakukan oleh guru adalah memberikan waktu kepada siswa 10 menit untuk membaca materi pelajaran yang telah dipersiapkan di rumah. Selanjutnya baru mulai untuk melaksanakan pembelajaran. Pertemuan 2 siklus 1 dilaksanakan tanggal 5 September 2016.

Pada pertemuan ini guru mulai melaksanakan proses pembelajaran dengan menggunakan metode Picture and picture. Pelaksanaan pembelajaran dilaksanakan dalam 3 kegiatan yaitu kegiatan awal, inti, dan penutup.

Pada pertemuan 2 siklus 2 suasana pembelajaran sudah mulai ada kemajuan. Kemampuan menjelaskan gambar pada pertemuan 1 ada 11 orang siswa, namun pada pertemuan 2 sudah meningkat jadi 14 orang berarti bertambah 3 orang. Kesimpulannya sudah ada kenaikan aktivitas siswa. Berikut akan dipetakan grafik aktivitas siswa pada pertemuan 2 siklus 1 .

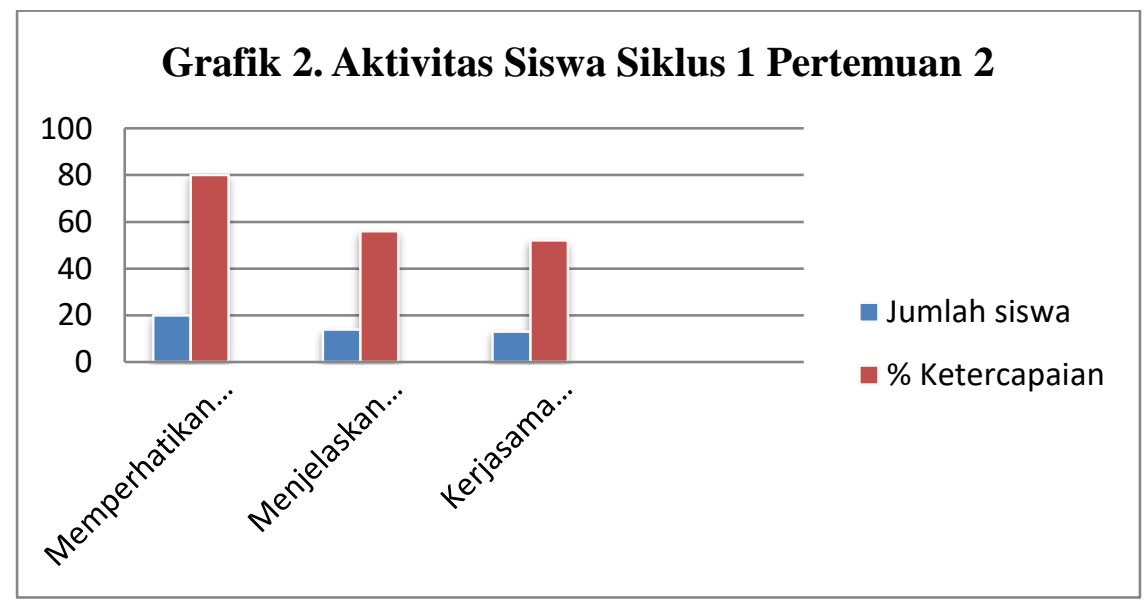


Pembelajaran sudah berjalan sesuai dengan yang diharapkan, namun dalam pelaksanaaanya perlu adanya perbaikan supaya lebih sempurna. Dalam pertemuan ke dua sudah kelihatan peningkatan aktivitas siswa dalam menjelaskan gambar, mencermati gambar namun perlu adanya perbaikan seperti menggunakan bahasa sesuai dengan kaidah bahasa Indonesia, sehingga tidak menimbulkan keributan di dalam kelas.

Untuk itu kekurangan-kekurangan yang ada pada siklus 1 dilaksanakan perbaikan agar tujuan pembelajaran yang telah ditetapkan tercapai. Maka siklus 2 dilakukan penyempurnaan dengan berpedoman pada siklus 1 tadi, dengan menyuruh siswa untuk melakukan hal-hal berikut:

1. Menugaskan siswa untuk menguasai materi pelajaran sehingga ia bisa menjelaskan gambar yang diamati.

2. Menugaskan siswa mencari contoh gambar di koran, majalah yang sesuai dengan materi yang dibaca.

3. Guru berusaha memotivasi yang kurang aktif agar bisa mengkomunikasikan gambar

\section{Siklus 2}

Pelaksanaan penelitian pada siklus 2 dibagi menjadi 2 pertemuan. Pertemuan 1 dilaksanakan Senin tanggal 19 September 2016 dan pertemuan 2 Senin tanggal 26 September 2016.

\section{Pertemuan 1}

Berdasarkan refleksi tentang proses pembelajaran pada siklus 1, maka disusunlah skenario pada siklus 2, sehingga terjadi perubahan yang berarti untuk lebih sempurnanya proses pembelajaran sesuai dengan harapan yaitu meningkatkan aktivitas siswa dalam belajar.

Adapun rencana tindakan yang dilakukan adalah :

1. Mengharuskan siswa membaca dan menguasai materi pelajaran di rumah sebelum proses pembelajaran sesuai indikator serta tujuan pembelajaran.

2. Menyusun Rencana Pelaksanaan Pembelajaran sesuai dengan langkah-langkah picture and picture.

3. Menyusun lembaran observasi untuk siswa dan guru.

4. Menyuruh siswa mencari contoh gambar-gambar yang berhubungan dengan materi pembelajaran.

5. Terus berupaya bagaimana supaya siswa termotivasi

Sesuai dengan tujuan penelitian yaitu meningkatkan aktivitas belajar siswa melalui metode picture and picture maka pemantauan pada siklus 2 juga dilakukan melalui lembaran pengamatan aktivitas siswa. Hasil siklus 2 pada pertemuan 1 dapat dilihat pada grafik 3 berikut ini. 


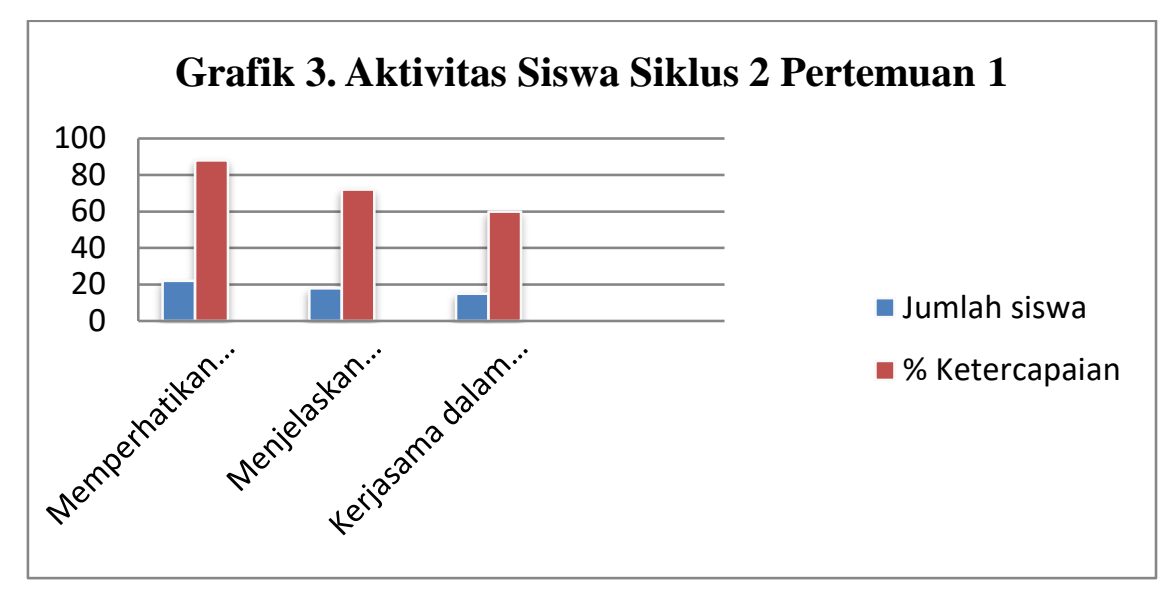

Dengan melihat aktivitas siswa pada pertemuan 2 siklus 1 ini terlihat tindakan yang diambil sudah menampakkan hasil yang memuaskan. Dalam proses pembelajaran yang dilakukan siswa sudah belajar menjelaskan gambar dengan benar bahwa yang digunakan sudah bisa bekerja sama dengan teman kelompok. Dengan demikian dapat disimpulkan bahwa secara kuantitatif rata-rata siswa bisa memperhatikan gambar 12 orang dengan persentase ketercapaian adalah 80\%, menjelaskan gambar 18 orang dengan persentase ketercapaian $72 \%$ dan kerjasama dalam kelompok 15 orang dengan persentase ketercapaian $65 \%$.

Untuk tercapainya tujuan yang telah direncanakan dalam tindakan ini maka diperlukan penyempurnaan apa yang sudah dilakukan pada pertemuan 1 yaitu :

1. Memberikan waktu yang cukup untuk mengkomunikasikan gambar yang dilihat siswa

2. Merubah posisi tempat duduk dengan cara mendekatkan tempat duduk siswa yang aktivitasnya tinggi dengan siswa yang aktivitasnya kurang agar mereka lebih dapat berdiskusi sebelum menjelaskan gambar

3. Menjelaskan kembali kepada seluruh siswa supaya lebih menguasai dan mendalami materi pertemuan berikutnya

\section{Pertemuan 2}

Berdasarkan hasil refleksi pertemuan 1 siklus 2, maka yang dilakukan guru pada pertemuan 2 siklus 2 adalah menemukan anggota kelompok siswa yang aktivitas rendah dengan tinggi serta menambah tinggi dari siswa untuk mengkomunikasikan/menjelaskan gambar. Jadi sebelum menjelaskan gambar siswa bisa berdiskusi dengan temannya terlebih dahulu.

Pelaksanaan pembelajaran pada pertemuan ini dibagi atas 3 tahapan yaitu kegiatan awal, kegiatan inti dan kegiatan penutup. Untuk melihat aktivitas belajar siswa maka hal ini dijelaskan dalam lembaran pengamatan. Berikut akan dijelaskan peningkatan aktivitas siswa dalam grafik 4 siklus 2 pertemuan 2 . 


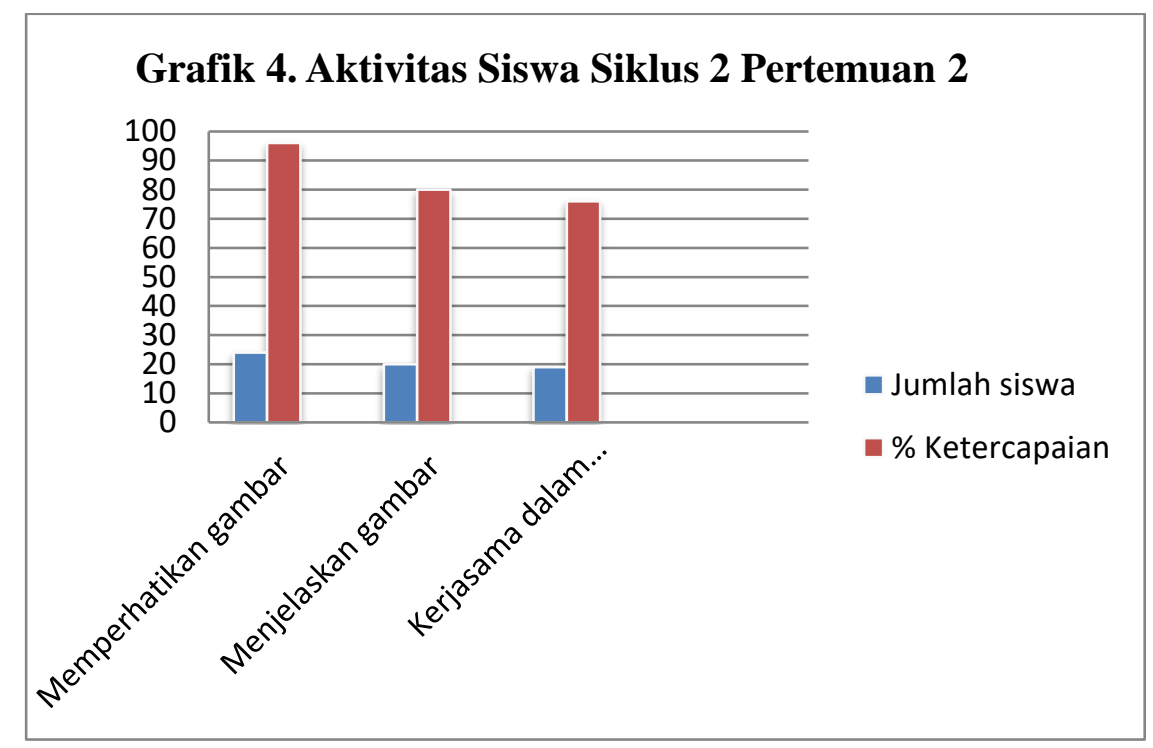

Dalam 2 grafik berikut ini (grafik 5 dan grafik 6) akan digambarkan beberapa aktivitas siswa yang terpantau pada siklus 1 dan siklus 2 .
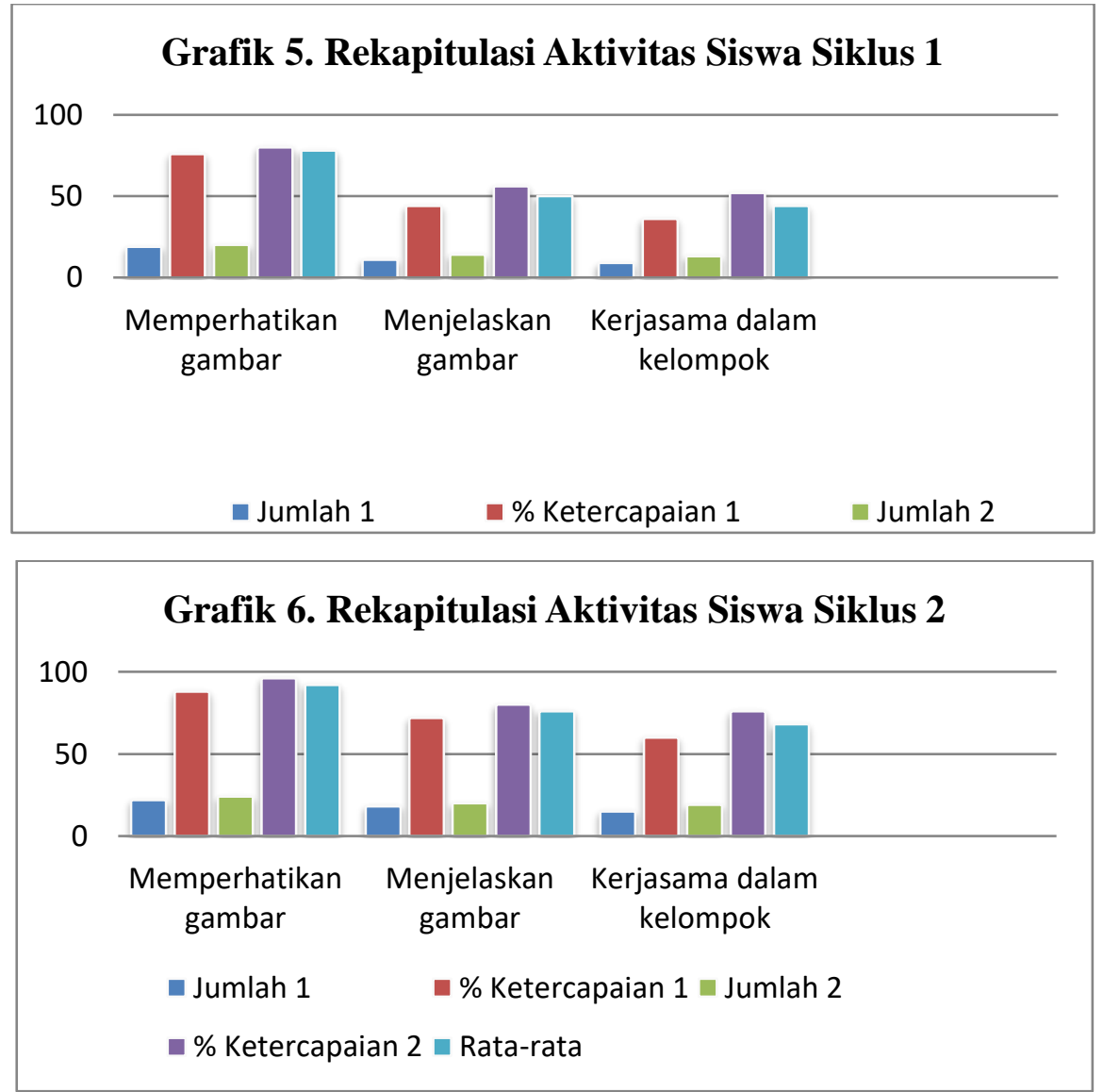

Melihat hasil yang dicapai dalam proses pembelajaran pada siklus II tampak bahwa tindakan yang dilakukan sudah mencapai hasil yang memuaskan. Dalam proses pembelajaran terlihat telah meningkatkan aktivitas siswa, siswa tampak 
berkonsentrasi, bersemangat, dan ada usaha untuk lebih memahami materi siswa dan siswa sudah dapat menjelaskan gambar yang diberikan oleh guru dan aktivitas siswa meningkat, maka dalam hal ini penulis merasakan penelitian sudah cukup dilakukan sampai pada siklus II.

Pada siklus 1 pertemuan 1 terlihat 9 (76\%) siswa yang memperhatikan gambar, $11(44 \%)$ siwa yang menjelaskan gambar dan 9 (36\%) siswa bekerja sama kurang beraktivitas dalam belajar, sehingga ditinjau dari segi teori ditemukan kelemahan dari metode picture and picture seperti yang dikemukakan oleh Hamdani (2011) bahwa kelemahan dari metode picture and picture adalah memakan waktu yang banyak dan banyak siswa yang tidak mau bekerjasama dengan orang lain. Berdasarkan data di atas berarti aktivitas belajar siswa rendah. Selanjutnya dilakukan perbaikanperbaikan dalam pertemuan selanjutnya dan selanjutnya guru memberi kesempatan kepada siswa untuk mengkomunikasikan gambar sebanyak-banyaknya. Pada pertemuan 2 siklus 1 terlihat data keaktifan siswa sebagai berikut: memperhatikan gambar 20 orang $(80 \%)$, menjelaskan gambar 14 orang $(56 \%)$ dan kerjasama dalam kelompok 13 siswa (52\%) dengan rata-rata $63 \%$. Hal ini berarti pada siklus 1 pertemuan 2 sudah ada peningkatan aktivitas siswa.

Untuk selanjutnya secara terus-menerus guru mengupayakan suasana rileks, tenang dan mengarah kepada meningkatnya aktivitas siswa sehingga siswa mampu mengkomunikasikan gambar atau menjelaskan gambar yang berhubungan dengan norma-norma yang berlaku dalam kehidupan bermasyarakat. Pada akhirnya membuktikan adanya dirasakan kelebihan dari metode picture and picture seperti yang dikemukakan oleh (Istarani 2014) bahwa materi yang diajarkan lebih terarah, siswa lebih cepat menangkap materi pelajaran, dapat meningkatkan daya nalar dan meningktkan tanggung jawab serta pembelajaran lebih berkesan.

Pada siklus 2 pertemuan 1 terlihat bahwa aktivitas siswa dalam memperhatikan gambar terindikasi ada 22 siswa (88\%), aktivitas siswa menjelaskan gambar ada 18 siswa (72\%) dan siswa yang bekerjasama ada 15 siswa $(60 \%)$. Persentase rata-rata aktivitas siswa adalah $73 \%$. Pada pertemuan berikutnya juga terjadi peningkatan aktivitas belajar siswa. Pada pertemuan 2 siklus 2 terlihat data sebagai berikut: Memperhatikan gambar 24 orang (96\%), menjelaskan gambar 20 orang $(80 \%)$ dan bekerjasama dalam kelompok sebanyak 19 orang $(76 \%)$. Dalam hal ini terlihat bahwa terjadi peningkatan aktivitas belajar siswa. Ini sejalan dengn penelitian terdahulu yang mengungkapkan bahwa penggunaan model picture and picture dalam proses pembelajaran dapat meningkatkan aktivitas siswa untuk mencapai ketuntasan belajar (Natalina et al. 2012).

Bila dicermati secara keseluruhan setelah dilakukan 2 siklus dengan 4 hari/kali pertemuan diperoleh peningkatan belajar siswa yang cukup signifikan. Aktivitas memperhatikan gambar pada siklus 1 rata-rata $78 \%$ meningkat menjadi $92 \%$. Berarti terjadi peningkatan $14 \%$. Aktivitas menjelaskan gambar dari rata-rata $50 \%$ meningkat menjadi $76 \%$ berarti naik $26 \%$. Aktivitas bekerjsama dalam kelompok dari $44 \%$ naik menjadi $68 \%$ berarti naik $24 \%$. Berdasarkan deskripsi tersebut maka dapat disimpulkan bahwa proses pembelajaran dengan model pembelajaran picture and picture dengan memperhatikan langkah-langkah pembelajaran dengan benar, dapat meningkatkan aktivitas siswa dan guru dalam proses belajar mengajar seperti yang pernah dilakukan oleh peneliti terdahulu 
seperti (Busro 2020). Bila dicermati data dan penjelasan di atas beserta hasil kajian terdahulu maka dapat disimpulkan bahwa penggunaan metode picture and picture dalam pembelajaran dapat meningkatkan aktivitas belajar siswa, termasuk dalam pembelajaran PKn di SMPN 2 Pariangan.

\section{Penutup}

Berdasarkan hasil penelitian dan pembahasan yang dikemukakan pada bagian sebelumnya maka dapat diambil beberapa kesimpulan sebagai berikut:

1. Penggunaan metode picture and picture dalam pembelajaran Pendidikan Kewarganegaraan (PKn) dapat meningkatkan aktivitas belajar siswa karena metode ini dapat menciptakan suasana belajar yang hidup dan gembira, mengarah cara berfikir siswa yang kritis.

2. Penggunaan metode picture and picture dapat meningkatkan kemampuan siswa untuk menguasai dan memahami materi pembelajaran secara lebih mendalam.

Berdasarkan kesimpulan di atas maka dalam penelitian penulis memberikan beberapa saran sebagai berikut:

1. Pembelajaran dengan menggunakan metode picture and picture dapat dijadikan sebagai salah satu alternatif dalam mengatasi permasalahan siswa yang aktivitasnya rendah dalam pembelajaran, termasuk dalam pembelajaran Pendidikan Kewarganegaraan (PKn).

2. Untuk menggunakan metode picture and picture perlu persiapan yang matang oleh guru berupa:

a. RPP (Rencana Pelaksanaan Pembelajaran)

b. Materi pembelajaran yang relevan

c. Gambar-gambar yang sesuai dengan materi pembelajaran.

\section{DAFTAR KEPUSTAKAAN}

Busro. 2020. “Upaya Meningkatkan Hasil Belajar Terjadinya Gerhana Bulan Dan Gerhana Matahari Melalui Metode Picture and Picture Pada Siswa Kelas VI SDN Munengleres I Kecamatan Sumberasih.” PEDAGOGY 7(1):48-51.

Dewi, Frisca Kumala. 2013. "Penerapan Model Picture and Picture Untuk Meningkatkan Keterampilan Menulis Deskripsi Pada Siswa Kelas II SDN Bringin 02 Semarang." Universitas Negeri Semarang.

Fauzi, R., Dwiastuti, S., \&. Harlita. 2011. "Penerapan Metode Pembelajaran Picture and Picture Untuk Meningkatkan Motivasi Belajar Biologi Siswa Kelas Viii D Smp Negeri 14 Surakarta Tahun Pelajaran 2011/2012 Application." Pendidikan Biologi 3(3):72-78.

Hamalik, Oemar. 2008. Proses Belajar Mengajar. Jakarta: Bumi Aksara.

Hamdani. 2011. Strategi Belajar Mengajar. Bandung: CV Pustaka Setia.

Hamid, Moh Sholeh. 2012. Metode Edutainment. Yogyakarta: Diva Press.

Istarani. 2014. 58 Pembelajaran Inovatif. Medan: Media Persada. 
Meiyanto, Tri Setyo, and Suwarsih. 2018. "Peningkatan Hasil Belajar Perkalian Melalui Model Picture and Picture Pada Siswa Kelas III Sekolah Dasar Negeri Peterongan Kota Semarang." Media Penelitian Pendidikan 12(1):92-101.

Mustikasari, Mega, Maddatauang, and Rosmini Maru. 2017. "UNM Geographic Journal." UNM Geographic Journal 1(1):48-54.

Nabilah, Fiyani, and M. Abdul Gofur. 2020. "PENINGKATAN KEMAMPUAN MENGENAL KOSAKATA BAHASA ARAB MELALUI METODE PEMBELAJARAN PICTURE AND PICTURE SISWA KELAS IB MI NURUL ANWAR BEKASI UTARA.” 03(April).

Natalina, Mariani, Yustini Yusuf, and Desy Rahmayani. 2012. "Penerapan Model Pembelajaran Kooperatif Picture and Picture Untuk Meningkatkan Aktivitas Dan Hasil Belajar Biologi Siswa Kelas Xi Ipa Sma N 1 Ukui Tahun Ajaran 2009/2010.” Jurnal Pendidikan Sains Dan Biologi X(1):24-35.

Passalowongi, Nadrah. 2020. "Meningkatkan Hasil Belajar Tema Lingkungan Tempat Tinggalku Melalui Model Pembelajaran Picture and Picture Siswa Kelas IV SD Negeri 18 Coppeng-Coppeng Kabupaten Barru.” 3(2):275-82.

Rakasiwi, Nilam, Wahyudi, and Endang Indarini. 2019. "Pengembangan Media Komik Dengan Metode Picture And Picture Untuk Meningkatkan Keterampilan Literasi Matematika Kelas Iv Pendahuluan Penyelenggaraan Pembelajaran Kurikulum 2013 Dirancang Agar Selama Proses Belajar Mengajar Siswa Menjadi Aktif Dalam Membang." Aksioma: Jurnal Matematika Dan Pendidikan Matematika UPGRIS Semarang 10(1):60-70.

Riyono, Bambang, and Amin Retnoningsih. 2015. "Efektivitas Model Pembelajaran Picture and Picture Dengan Strategi Inkuiri Terhadap Motivasi Dan Hasil Belajar Siswa." Journal of Biology Education 4(2):166-72. doi: 10.15294/jbe.v4i2.8907.

Sagala, Saiful. 2003. Konsep Dan Makna Pembelajaran. Bandung: Alfabeta.

Sardiman. 2007. Interaksi Dan Motivasi Belajar Mengajar. Bandung: Rajawali Pers.

Slameto. 2015. Belajar Dan Faktor-Faktor Yang Mempengaruhinya. Jakarta: Rineka Cipta.

Sudarsana, I. Wayan, Kadek Eva Krishna Adnyani, and Ni Nengah Suartini. 2018. "Penerapan Metode Picture and Picture Untuk Meningkatkan Penguasaan Kosakata Bahasa Jepang Siswa Kelas X Ap 2 Smkn 1 Nusa Penida Tahun Ajaran 2017/2018.” Jurnal Pendidikan Bahasa Jepang Undiksha 4(1):63. doi: 10.23887/jpbj.v4i1.14662.

Suprijono, Agus. 2011. Model-Model Pembelajaran. Jakarta: Gramedia Pustaka Jaya. 